\title{
Refuge
}

Canada's Journal on Refugees

revue canadienne sur les réfugiés

\section{Deport. Deprive. Extradite: 21st Century State Extremism by Nisha Kapoor}

\section{Marsha Rampersaud}

Volume 35, Number 1, 2019

Racialized Refuge

URI: https://id.erudit.org/iderudit/1060678ar

DOI: https://doi.org/10.7202/1060678ar

See table of contents

Publisher(s)

Centre for Refugee Studies, York University

ISSN

0229-5113 (print)

1920-7336 (digital)

Explore this journal

Cite this review

Rampersaud, M. (2019). Review of [Deport. Deprive. Extradite: 21st Century

State Extremism by Nisha Kapoor]. Refuge, 35(1), 84-85.

https://doi.org/10.7202/1060678ar

This document is protected by copyright law. Use of the services of Erudit (including reproduction) is subject to its terms and conditions, which can be viewed online.

https://apropos.erudit.org/en/users/policy-on-use/ 
We Know It ... and I Feel Fine': Considering a Postnational World," by Farida Fozdar, discusses limited acceptance of the notion of open borders and world citizenship, and illuminates the arbitrariness and discrimination of current immigration policy and the future on Australians' engagement with the idea of borderlessness as an aspect of cosmopolitan thinking. Karen Farquharson, David Nolan, and Timothy Marjoribanks in their chapter 9, "Race' and the Lived Experiences of Australians of Sudanese Background," explore how Sudanese and South Sudanese migrants to Australia view and experience their portrayal and representation by Australian news media, and how this affects their life.

Part 4, "Cosmopolitanism and Transnationalism," contains Loretta Baldassar's chapter 10, "Australian Migrant Families and the Transnationalisation of Care," which examines the growing interest and analysis of women, migration, transnational family relations, and caregiving across distance, and the role of new technologies in these processes. It also considers recent changes in contemporary Australian migration policy on temporary migration visas, that shift from family reunion migration, cohesion, and settlement, to family separation and mobility. Val Colic-Peisker in chapter 11, "Capitalism and Cosmopolitanism: A Very Australian Juxtaposition," while examining contemporary Australia as a "cosmopolitan" but also intensely "capitalistic" country, focuses on the Australian juxtaposition of capitalism and cosmopolitanism in the context of the latest wave of globalization and Australia's place in the globally dominant "Anglosphere." Chapter 12, "Public Spaces in the Context of the Networked Citizen and Multicultural Societies," by Nikos Papastergiadis, Paul Carter, Scott McQuire, and Audrey Yue, addresses the new conditions of public culture emerging via urban design, cultural practices, public participation, and digital and media platforms.
Part 5, "Multiculturalism and Constructions of Cultural Identity," begins with chapter 13, "Sociology of Youth and Migration Research," by Anita Harris, in the context of globalization, diversity, and mobility, with a particular focus on Australia, reflects on the ways one has to construct migrant background youth as a unit of inquiry within the fields of youth sociology and migration studies. Vince Marotta and Paula Muraca in their chapter 14, "Transnational Otherness and the Paradox of Hybridity in Singapore and Australia: A Critical Realist Approach," examine the conceptualization of hybridity and its relationship to the discourse of multi-racialism and multiculturalism in Singapore and Australia. Chapter 15 by Greg Noble and Paul Tabar, "The 'Career' of the Migrant: Time, Space and the Settling Process," centres on the question of how migrants settle, based on a case study that examines the settling experiences of Lebanese migrants to Australia. It argues that settling is not an event but a trajectory whose temporal and spatial dimensions need to be explored.

Martina Boese and Vince Marotta's book fills important gaps in the study of migration, race, and multiculturalism and brings important analyses on theoretical and research levels of prominent scholars in the field while offering rich materials. It may serve as an extremely useful guide for academics, researchers, students, NGO and aid workers, human rights professionals, social workers, asylum service workers, public organizations, and those working on refugee and migration policy, migration, and race.

Theodoros Fouskas (sociologist, PhD) has taught at the University of Crete (2017-18, NSRF, teaching scholarship), the National School of Public Health (2017-18), the Democritus University (2017-18), and other academic institutions. The author can be reached at theodoros.fouskas@gmail.com.

\title{
Deport. Deprive. Extradite: 21st Century State Extremism
}

\author{
$\sim$ \\ Nisha Kapoor \\ London: Verso, 2018, 240 pp.
}

I n Deport, Deprive, Extradite, Nisha Kapoor shares the plight of Muslim men suspected of terrorism-related offences in the United Kingdom. Positioned in a discussion of racism, state violence, and injustice, Kapoor talks of their detention and deportation as part of a burgeoning security regime. Her principal focus, however, is on extreme cases of extradition. Extradition, "in its starkness, makes more visible what may be obscured in less extreme forms, and so brings to light broader trends of securitisation and dispossession" (6). Kapoor uses these cases to address two research questions: "[1] What can the stories of those criminalised as terrorism suspects and expelled reveal about shifts in the state of security? [2] How do these cases help to further the agendas of securitisation, marginalisation and racial 
exclusion?" (14). In Kapoor's efforts to answer these questions, she uncovers and problematizes militarized policing practices, impartiality in the courts, and limits and conditions placed on citizenship and human rights (15). These discussions will be of particular interest to an audience engaged in politics, sociology, law, and activism.

Babar Ahmad's story is one of unwarranted brutally violent apprehension by state police (51-2). Babar's story helps Kapoor illustrate the current merging of civilian and militarized policing (42). She suggests that the infrastructure and practice of policing working-class communities of colour had already existed prior to the emergent threat of terrorism. This established framework that focuses on "managing and disciplining 'dangerous' bodies in the name of public protection" (60) serves to "normalise and rationalise forms of state violence that could be otherwise presented as excessive or exceptional" (56). According to Kapoor, Babar's case highlights the fact that violence carried out by the state is [always] recognized as legitimate, whereas terrorism is always recognized as illegitimate violence (47-8). She argues that "the issue is not so much the form that violence takes or what modes and mechanisms are used to commit it, but who it is committed by and who it is legitimate to commit it upon" (49). Kapoor acknowledges that there are individuals who engage in futile violence, but she cautions against a logic and processes that collectively criminalize certain populations (11). Such thinking works to categorize individuals into those worthy of state protection and those deemed to be targets of state violence (142), or, as Kapoor sees it, humans and nonhumans (37).

Kapoor shares the story of Haroon Aswat's extradition to the United States, despite a ruling in the European Court of Human Rights (ECHR) to the contrary (116), to illustrate the converging interests of the executive and legislative branches: when faced with extradition requests from the United States, British courts have consistently departed from earlier safeguards in extradition laws (123). Kapoor highlights cases in which courts have permitted low or non-existent benchmarks for evidence $(3,33)$, the admission of information obtained through unlawful interrogations carried out under torture (34), and secret hearings of which neither the accused nor their legal counsel were allowed to attend (33). These practices all work to expedite extraditions. When existing laws have not served their desired purpose, Kapoor illustrates how the two branches have worked together to either supersede these laws, or even to create new laws to meet their ends (130).

Kapoor further argues that the threshold that determines one's inclusion (or exclusion) from the British polity is drawn on raced, classed, and gendered terms (89). Her specific concern is the state's power to withdraw citizenship from those deemed to be "terrorists" (17). In the story of Minh Pham's denaturalization and subsequent statelessness (88) Kapoor shows that citizenship is delimited and conditional, and can be withdrawn from particular populations (89). Furthermore, the relational inclusion-exclusion dialectic upon which citizenship rests has material consequences for those who are excluded and consequently deemed non-human (89). Kapoor reveals one such consequence as the legitimated deprivation of one's human rights entitlements. The story of Haroon Aswat's extradition further illustrates the imagined juxtaposition between "British citizens" and "terrorism suspects" in the question of rights entitlements (118). Despite the ECHR's ruling that Haroon's mental health would be compromised if he were extradited, which violates his human rights, the British executive and legislative branches worked together to orchestrate his extradition. Some politi$\mathrm{cal}$ and academic commentators have argued that the choice to participate in terrorism is effectively a forfeiture of one's rights protections (10). Reasoning from this perspective, courts such as the ECHR have enshrined in law the premise that extending human rights to terrorism suspects would be a misapplication of human rights (116). Such assertions lead Kapoor to interrogate who counts as fully human (118).

If there were one weakness in Kapoor's work, it would be her treatment of gender. She alerts the reader to the increasing numbers of women being targeted as potential terror suspects and also families who have had their children apprehended in the name of pre-emptive policing, but neither concern is developed fully (155). Rather, these arguments seem to stand alone in her final chapter. Also, whereas each of the issues she discusses features a real-life narrative, this is missing from her gender discussion. With that being said, I gather that these are emergent issues and that perhaps much of the literature focuses primarily on Muslim men. In this case, Kapoor has succeeded in placing these issues on readers' radars. Readers looking for intersectional analyses are encouraged to read Kapoor's work within the broader bodies of literature devoted to gender and terrorism.

The issues raised in Deport, Deprive, Extradite are timely. This work sheds much-needed light on militarized policing, impartiality in the courts, and the suspension of citizenship and human rights for particular bodies. Kapoor's anecdotal method adds names to these issues, which humanizes them and makes them impossible to ignore. What results is an evocative and alarming account of injustice at the hands of the state. This work is a key piece in the War on Terror literature.

Marsha Rampersaud is a PhD candidate at Queen's University. She can be reached at rampersaud.marsha@queensu.ca. 